\title{
Coffee Production Systems: Evaluation of Intercropping System in Coffee Plantations in Rwanda
}

\author{
A. Harelimana ${ }^{1,2}$, G. Le Goff ${ }^{2}$, D. T. Ntirushwa Rukazambuga ${ }^{1} \&$ T. Hance ${ }^{2}$ \\ ${ }^{1}$ College of Agriculture, University of Rwanda, Busogo Campus, Huye, Rwanda \\ ${ }^{2}$ Biodiversity Research Center, Earth and Life Institute, Univrsité Catholique de Louvain, Louvain-la-Neuve, \\ Belgium \\ Correspondence: A. Harelimana, Biodiversity Research Center, Earth and Life Institute, Univrsité Catholique de \\ Louvain, Louvain-la-Neuve, Belgium. Tel: 32-(0)-466-284-960. E-mail: anastase.harelimana@uclouvain.be
}

Received: April 8, 2018

doi:10.5539/jas.v10n9p17

\author{
Accepted: June 20, $2018 \quad$ Online Published: August 15, 2018 \\ URL: https://doi.org/10.5539/jas.v10n9p17
}

\begin{abstract}
Intercropping is an agricultural practice consisting in planting two or several crops in the same field simultaneously. This production system appeared to offer an excellent several advantages. While intercropping has been widely practiced since ancestral times, there was a lack of data in Rwanda on the kind of intercrops mostly used and on farmers' perception of their utility and constraints. The main objectives of this work were (1) to assess the different food crops associated with coffee trees in Rwanda and (2) to determine the perception of farmers on the role of intercropping system. That was why a field survey was carried out between August $25^{\text {th }}$, 2014 and February $28^{\text {th }}, 2015$ in Kamonyi District of Rwanda. Seventy-five coffee producers were randomly selected and contacted to fill a questionnaire on their practices. The correlation between yield and pesticide application were performed using $\mathrm{R}$ version. The significance level $\mathrm{P}$ was set at 0.05 . Results revealed that common beans (Pheseolus vulgaris L.) and soybeans (Glycine max L.) were the most coffee intercropped plants. It appeared that intercropping was practiced to ensure the production of staple crops beside coffee. Insecticide remained the main way to control coffee pests and there was thus an important work to find alternative solutions that are often ecologically non-disruptive. Plant breeders and extension agents should investigate plants that are suitable to intercrop with coffee trees in order to enhance the conservation agriculture.
\end{abstract}

Keywords: biodiversity, Coffea arabica L., conservation agriculture, intercropping system, Rwanda

\section{Introduction}

Intercropping is the practice of growing more than one crop in the same field at the same time (Wezel et al., 2014). The most common goal of intercropping is to generate a wide variety of yields per land surface (Mendez et al., 2010) by using resources that would otherwise be taken up by a single crop (Schroth \& Ruf, 2014). For instance, Nitrogen fixing trees (e.g. fruit trees: Inga) and annual crops (e.g. soybeans) intercropped with coffee can restore soil fertility and generate a diversity of agricultural produce like fruits, firewood and timber, which can increase the food security and income of rural communities (Souza et al., 2010). This coffee production system provides income for rural communities whose land is limited and helps farmers to reduce the risk associated with drought (Perfecto \& Vandermeer, 1996), pest attack (Soto-Pinto et al., 2002) and coffee price volatility (Jassogne et al., 2013). Intercropping exhibits greater yield stability and less productivity decline during a drought than in the case of a single crop; it also regulates the problem of water stress by keeping humidity within crops (Altieri \& Koohafkan, 2008). In El-Salvador, shade trees in coffee plantations provide firewood for smallholder households for an equivalent value of 1 month of income generated by all members of the household (Bacon, 2005). In Nicaragua, where it is usually practiced by small-scale farmers, $60 \%$ of the farmers grow half or more of the food they eat and coffee is currently intercropped with corn, beans and bananas (Bacon, 2008). The diversification of produce (avocados, pawpaw, banana, cassava, sugarcane, beans, soybeans, peas, potatoes) together with the strategy of farm-gate guarantees farm stability during the period of reestablishment of coffee production (after rejuvenation pruning) (Souza et al., 2012). In addition to income generation and food security, the intercropping system in coffee plantations is an approach to producing organic coffee that provides a number of assets that are important for optimal livelihood in rural communities, such as participation in cooperative and local associations as well as access to water, land and loans (Bacon, 2008). 
Intercropping in coffee plantations improves soil fertility as organic material from the trees or crops is integrated by the soil, resulting in an improvement of soil quality that enhances the main crop's ability to compete with weeds (Pumariño et al., 2015), saving farmers the cost of expensive nitrogen fertilizers. It increases microbial diversity such as vesicular arbuscular mycorrhizae populations, which provide nutrient to the plants (Bainard et al., 2011). As they cover an important part of the soil, intercropped plants produce more shade, keep soil humidity and create more buffer microclimatic conditions (Siles et al., 2010). It also improves both physical (porosity) and chemical soil properties (soil pH, enzymes) (Wang et al., 2015). In Parana State in Brasil, coffee was intercropped with the cultivation of legumes, especially Leucaena leucocephala L. (Fabales: Mimosaceae), which significantly increased the soil enzyme activity (urease, arylsulfatase and phosphatase) as well as the Carbon and Nitrogen mineralization rates (Balota \& Chaves, 2010). Intercropping is also a solution to conserve soil fertility by reducing soil erosion (splash effect, lixiviation and leaching) (Bucagu et al., 2013).

Intercropping negatively influences the abundance of plant pest populations through different mechanisms. For example, onions (Allium cepa L.) may be planted with carrots (Daucus carota L.) to mask the carrot smell for carrot flies. In the same way, the pest of cabbage Plutella xylostella (Lepidoptera: Yponomeutidae) was reduced using Barbarera vulgaris L. (Capparales: Brassicaceae) and the pest of cotton Helicoverpa spp (Lepidoptera: Noctuidae) was reduced using pea association (Pisum sativum L.) (Ratnadass et al., 2012). The density of plants facilitates the spread of pathogens and pests. This is the case with soil nematodes Meloidogyne exigua (Tylenchida: Meloidogynidae) and Pratylenchus coffeae lato (Tylenchida: Pratylenchidae) which are spread through injured/wounded roots. The introduction of a non-host plant can help to intercept pests and diseases when spreading or dispersing (Avelino et al., 2011). Concerning the intercropping in coffee trees, much experimental and empirical work has been done, pushed by economic necessity in Central America. Concerning crop protection, the valued incidence of pathogens like coffee rust and pests such as Hypothenemus hampei (Coleoptera: Cuculionidae) and Leucoptera coffeella (Lepidoptera: Lyonetiidae) is significantly reduced in farms where intercropping is practiced (Avelino et al., 2011; Pumariño et al., 2015). Several mechanisms may be involved in reducing pest problems. (1) First, the Natural Enemies hypothesis predicts that predator and parasitoid should be more abundant in polyculture than in monoculture because of the increased number of niches and resources available (Russell, 1989; Straub et al., 2014), (2). The resource concentration hypothesis states that pest species are attracted by plots where their host-plants are the most abundant (Grez \& Gonzalez, 1995). These two mechanisms are complementary. In consequence, by changing the vegetation structure, the presence of several cultivated plant species on the same plot may reduce the attractiveness of the target crop by dilution or even by the repellent effect of the other crops (Bleeker et al., 2011). (3) A practical consequence of this point is a change in pest settling on the crop. Indeed, when landing on a non-host plant; the pest will tend to fly away and to leave the plot (Straub et al., 2014). (4) Trap plants and trap crops, for example, Pennisetum purpureum Schumach (Sperales: Poaceae) (Khan et al., 2010), defined as plant stands deployed to attract, divert, intercept or retain targeted insects or the pathogens they vector in order to reduce damage to the main crop are another mechanism involved in intercropping efficiency, and this is considered as a promising technique (Ratnadass et al., 2012).

The conservation of biodiversity in coffee orchards depends on social factors such as the distance a farmer has to work to reach the field, different types of support networking both technical and financial, and ecological factors such as landscape, arrangements of crops within fields and seed sources (Bacon et al., 2005), showing that biological conservation requires more effort. However, in spite of much effort being required, it can be retrieved through the provision and regulation, as well as cultural and supporting services that it gets from the ecosystem. Intercropping contributes to biodiversity conservation and the provision of ecosystem services (De Beenhouwer et al., 2013). A comparison between shaded coffee with sun-exposed coffee trees in Puerto Rico indicated that the shaded coffee was comparable to the natural forest due to its capacity to harbor a wide variety of animal species (birds, lizards and amphibians) (Buechley et al., 2015). Intercropping does not only have a positive impact on vertebrate animals but also on invertebrates. The use of the agro-ecological method in food production, particularly the intercropping system, with the aim of keeping a wide variety of flowering plants within and around the fields (food concentration and variability hypothesis) increases pollinator insects (Nicholls \& Altieri, 2013). In Nicaragua, shade coffee landscapes are important because they welcome a huge biodiversity and mitigate some effects of climate change (Bacon et al., 2008). Additionally, the intercropping system contributes to detoxification of the biosphere. Agricultural lands are a major potential sink and could absorb large quantities of Carbon if trees are reintroduced into these systems and judiciously managed together with crops (Albrecht \& Kandji, 2003). 
In Rwanda, coffee (Coffea arabica L.) is the foremost source of income for rural poor communities (Bigirimana et al., 2012). The intercropping system dominates monoculture because most coffee trees belong to smallholders, and many coffee growers in East Africa, particularly in Rwanda, are individual smallholders. Coffee trees are always associated with food crops, fruit trees and agroforestry trees for fodder. This paradoxical technique is not specific to Rwanda in Africa. For example, in order to increase coffee production and improve the livelihood of rural communities of Uganda, coffee is currently intercropped with banana (Jassogne et al., 2013). But in Kenya coffee is associated with different crops such as maize, tomatoes, beans, soybean and banana (Njoroge et al., 1993). Coffee growers in Rwanda are facing many problems such as potato taste defect caused by the pentatonic bug, Antestiopsis orbitalis (Coleoptera: Pentatomidae), instability of the price at the regional and international markets, drought, the reduction of arable land due to population pressure, and the lack of high yield varieties. Under these conditions, coffee alone is not promising to satisfy all the needs of the rural communities, and coffee growers have sought alternative sources of income and food when coffee income is depleted. This traditional agriculture system is practiced in the whole of East Africa (Rwanda, Burundi, Tanzania, Uganda, Kenya, and Ethiopia) and is helping farmers to get subsistence, increase incomes, and avoid over-reliance on a limited number of agricultural commodities (Matusso et al., 2014; Mucheru-Muna et al., 2010). Disadvantages such as the competition for resources, space and light as well as the difficult work of plant management (Ratnadass et al., 2012) are compensated by yield diversification (Machado, 2009). Although intercropping of coffee with food crops has been practiced since many years ago, there is a lack of documented information on how and what crops are suitable to intercrop with coffee to improve both the life of rural communities and biodiversity. Our objectives were (1) to determine the most frequent food crops associated with coffee and why, (2) to evaluate the perception of rural communities on the importance of intercropping, particularly the role of coffee-food crop intercropping on biodiversity conservation, (3) to know the other agricultural practices that are used, including insecticide application, and (4) to sort out the importance of intercropping in coffee trees. Understanding the linkages between intercropping of coffee trees with food crops and household livelihoods can provide insight into how this paradoxical system can be used to support both conservation agriculture and livelihood strategies.

Countries like Uganda have already documented intercropping of coffee with food crops and pointed out the advantages in terms of improving the livelihood of rural communities and in terms of quality and quantity of coffee production intercropped with banana (Jassogne et al., 2013). It was very crucial to gather more information on intercropping system in Rwanda and its implication in livelihood improvement of coffee farmers. The present work aimed to evaluate the coffee production system within small plots in rural communities with focus on the intercropping system. It allowed us recommending choice in the context of biological conservation in landscapes under agriculture production and livelihood improvement for coffee smallholder farmers.

\section{Materials and Methods}

\subsection{Survey Area Description}

Farmer practices were investigated between the end of $25^{\text {th }}$ August 2014 and $28^{\text {th }}$ February 2015 in Kamonyi in the Southern Province of Rwanda (Figure1). The research has been carried out in three sectors: Runda, Gacurabwenge and Mugina (Figure 1).

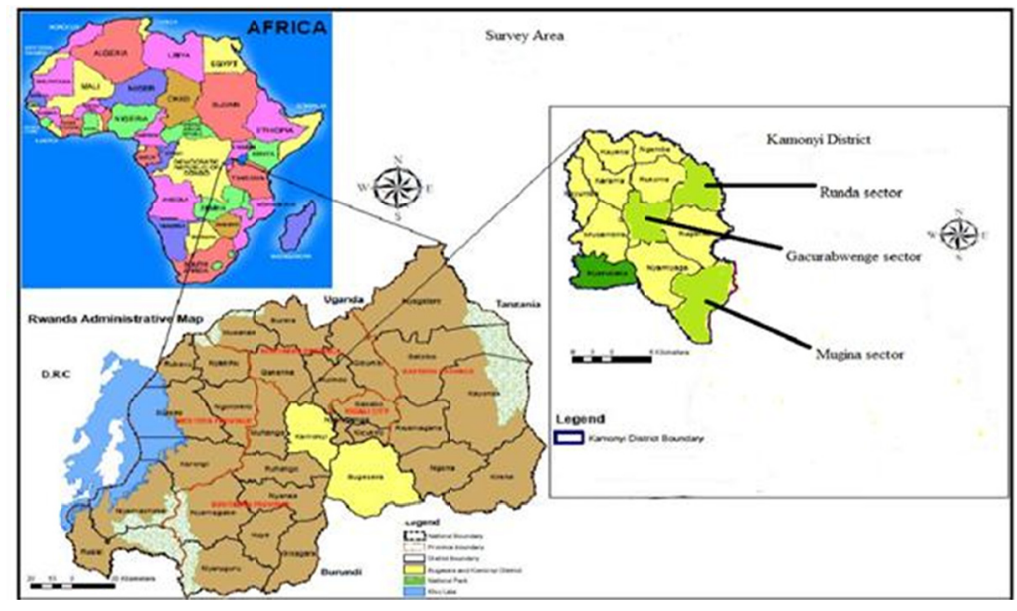

Figure 1. Site description map showing the area where the research has been carried out 


\subsubsection{Climate}

The altitude (study area) ranges from 1200 to $1800 \mathrm{~m}$ with a gently undulating topography while the altitude in Rwanda ranged between $900 \mathrm{~m}$ and $4500 \mathrm{~m}$ above sea level (Rushemuka et al., 2014). A large number of rivers found in this zone constitute the major water resources for human and cattle consumption. The mean annual temperature is around $21^{\circ} \mathrm{C}$ and relative humidity is $55-75 \%$ (Table 1) (Mujawamariya, 2012).

Table 3. Main biophysical characteristics and socio-economic indicators of Kamonyi District in Rwanda

\begin{tabular}{lll}
\hline B. characteristics & Unit & \\
\hline Latitude \&longitude & - & $02^{\circ} 06^{\prime} \mathrm{S} ; 29^{\circ} 48^{\prime} \mathrm{E}$ \\
Altitude & $\mathrm{m}$ & 1805 \\
Annual mean rain fall & $\mathrm{mm}$ & $1068 \pm 49$ \\
Total annual temperature & ${ }^{\circ} \mathrm{C}$ & 20 \\
Topography & - & flat to undulating \\
Socio economy indicators & $\mathrm{In} / \mathrm{km}^{2}$ & 339 \\
Population density & $\mathrm{Ha}$ & $0.02-0.07$ \\
Common farm size & meter; $\mathrm{mm}=$ millimeter; ${ }^{\circ} \mathrm{C}=$ Degree Celsius; $\mathrm{In} / \mathrm{km}^{2}=$ Inhabitants $/ \mathrm{km}^{2}, \mathrm{Ha}=$ hectare.
\end{tabular}

Note $. \mathrm{m}=$ meter; $\mathrm{mm}=$ millimeter $;{ }^{\circ} \mathrm{C}=$ Degree Celsius; $\mathrm{In} / \mathrm{km}^{2}=$ Inhabitants $/ \mathrm{km}^{2}, \mathrm{Ha}=$ hectare .

\subsection{Methods}

\subsubsection{Questionnaire}

In order to define the agricultural practices in this region, the interviewed farmers were asked questions. They bordered on (1) the origin of coffee seedlings, (2) the date of planting, (3) the main food crops associated with coffee plants, (4) their interests of intercropping system in coffee production, (5) the plant species used to control erosion around and within coffee plantations, (6) the major coffee pathogens, and (7) the pesticides most frequently used to control pests in coffee plantation. Question one is motivated by the fact that several varieties only are supported by the agricultural authorities, but these varieties differ regarding their susceptibility to major pests.

\subsubsection{Identification of Coffee Producers}

Coffee cooperatives supplied the list of coffee producers. Farmers were selected based on number of coffee plants, area under coffee production (at least 5 ares) and experience in coffee production (more than ten years). The selection criteria retained 93 farmers. The number of farmers is still for us high for sampling. We determined require sample size using the formula 1 proposed by Israel (1992) that could represent 93 farmers. After that, seventy-five farmers were randomly selected to respond to the questionnaire.

$$
\mathrm{n}=\frac{\mathrm{N}}{1+\mathrm{N}(0.05)^{2}}
$$

Where, $\mathrm{N}=$ Population size (in this case $\mathrm{N}=93$ farmers); $\mathrm{n}=$ sample size; the significance level of $\mathrm{P}=0.05$.

\subsubsection{Qualitative Data Collection}

On $26^{\text {th }}$ August 2014 , detailed farm characterizations were conducted using a rapid survey. To assess socio-economic conditions related to intercropping system within each household, field measurements were obtained from cooperatives where smallholders sold coffee berries and were supplemented by survey and observation. From $25^{\text {th }}$ August 2014 till $28^{\text {th }}$ February 2015, observations were conducted in parallel with the interview to check the food crops associated with the coffee and plant species used to control soil erosion around coffee plantations. After field work, all completed questionnaires were then smoothly checked for completeness, accuracy and uniformity. A semi-structured interview was used to collect information and the perception of farmers on their practices. The questionnaire was administrated face-to-face to each selected farmer. Coffee producers were helped to understand questions that they were requested to respond to. Each household was visited separately and solicited to allow us to visit their coffee plot. The collected information was kept in a database for further analysis.

\subsubsection{Quantitative Data Collection}

On February $28^{\text {th }}, 2015$, the quantity of pesticides and fertilizers that every interviewed farmer applied were obtained from the factory/coffee washing station where they usually sell fresh coffee berries (historical record of 
every farmer). From this factory, we also got the price on fresh berries, the number of coffee trees for each farmer and the yield per coffee plant for each interviewed farmer. After getting the results, in order to interpret and clarify them, between February $20^{\text {th }}, 2016$ and September $20^{\text {th }}, 2016$, a complementary interview (discussion) was carried out on the same individuals. No new specific questions were used; it was just to get more information and clarification on the obtained results.

\subsection{Statistical Analysis}

The correlation between yield and pesticide application were performed using R version 2.14.1 (Copyright (C) 2011, the R Foundation for Statistical Computing for Mac). The significance level of $\mathrm{P}$ was set at 0.05 .

\section{Results}

All 75 coffee farmers responded to the questions. However, 3 farmers were not able to answer the question on naming pesticides usually used to control pests in coffee plots. For all the 75 farmers visited, plots were well managed and usually intercropped with one cultivated plant and in some cases with two. Intercropping of food crops with coffee was practiced at least twice per year.

In the past, coffee farmers used to keep a part of their production (coffee beans) as the source of seedlings for the next season. Today, in order to increase yield, $66.7 \%$ of the farmers used prepared seedlings at low cost for farmers by the services of the government of Rwanda through the private sector, and trained agricultural cooperative seedling multiplicators got seeds for seedling preparation from farmer phytosanitary inspected plots. It meant that $33.3 \%$ of coffee farmers in Kamonyi District still got seedlings from their own plots.

The planting date depends on the availability of seedlings. It was in this context that some farmers plant in December while others begin only to plant in February. In Rwanda, in most cases, coffee was planted between October and November and replanting takes place in March. Except for perennial crops such as pineapples and citrus that remain associated with coffee for many years, coffee was intercropped with annual crops from September to November and from January to April. Intercropping was practiced in $100 \%$ of the cases during the first 3 years after plantation and after regeneration pruning (Figure 2).
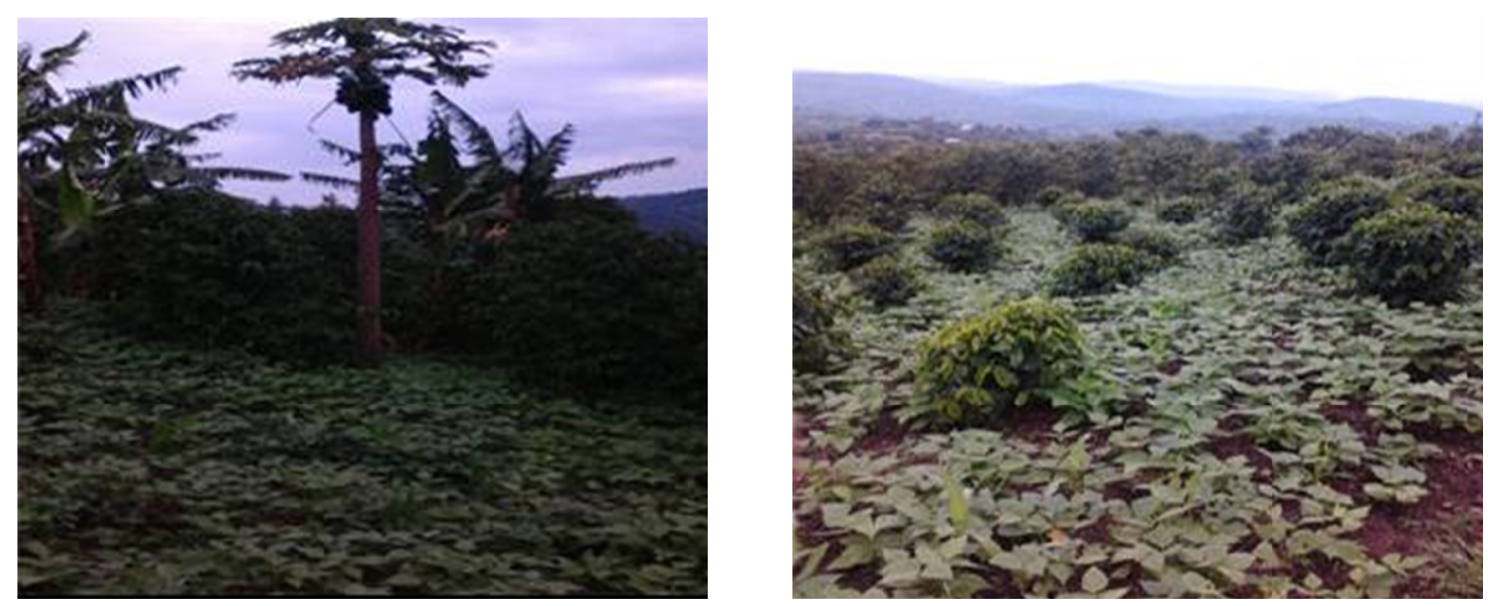

Figure 2. Coffea arabica associated to beans, banana, pawpaw, cucumber and potatoes in season A (September-December). Photo was taken in Rwanda, November 2014

Among the farmers interviewed, coffee was intercropped in $90.7 \%$ of the cases with many annual crops while 9.3\% intercropped coffee trees with one food crop. The most frequent crops associated with coffee were beans (Phaseolus vulgaris L., 61.3\%), taro (Colocasia esculantas L., 34.7\%), maize (Zea mays L., 29.3\%), soybean (Glycine max L., 25.3\%), peas (Pisum sativum L., 4\%), cucumber (Cucumis sativus L., 2.\%), groundnuts (Arachis hypogaea L., 0.5\%), pineapple (Ananas comosus L., 0.485\%), cassava (Manihot esculenta Crantz., $0.01 \%$ ), banana (Musa acumunata Colla.) and potato (Solanum tuberosum L.).

Concerning the reason farmers choose to intercrop coffee, nobody indicated to have chosen the intercropping system to control pests and pathogens or improve ecosystem services. However, the intercropping system was currently practiced for several reasons. First, farmers wish to maximize crop production on small plots of land. Second, they want to diversify their agricultural produce, manage weed, keep soil humidity and improve soil 
fertility without buying any kind of input. The common objective of polyculture in the surveyed area is for subsistence and diversification of agriculture produce. In Rwanda, many plantations of coffee were done on hillsides and were thus more exposed to soil erosion. Results showed that soil erosion within coffee plantation was controlled by intercropping coffee with reed Pennisetum purpureum Schumch (Poaceae). It was also used to mulch coffee and to feed domestic animals such as goats and cows (Figure 3 ).
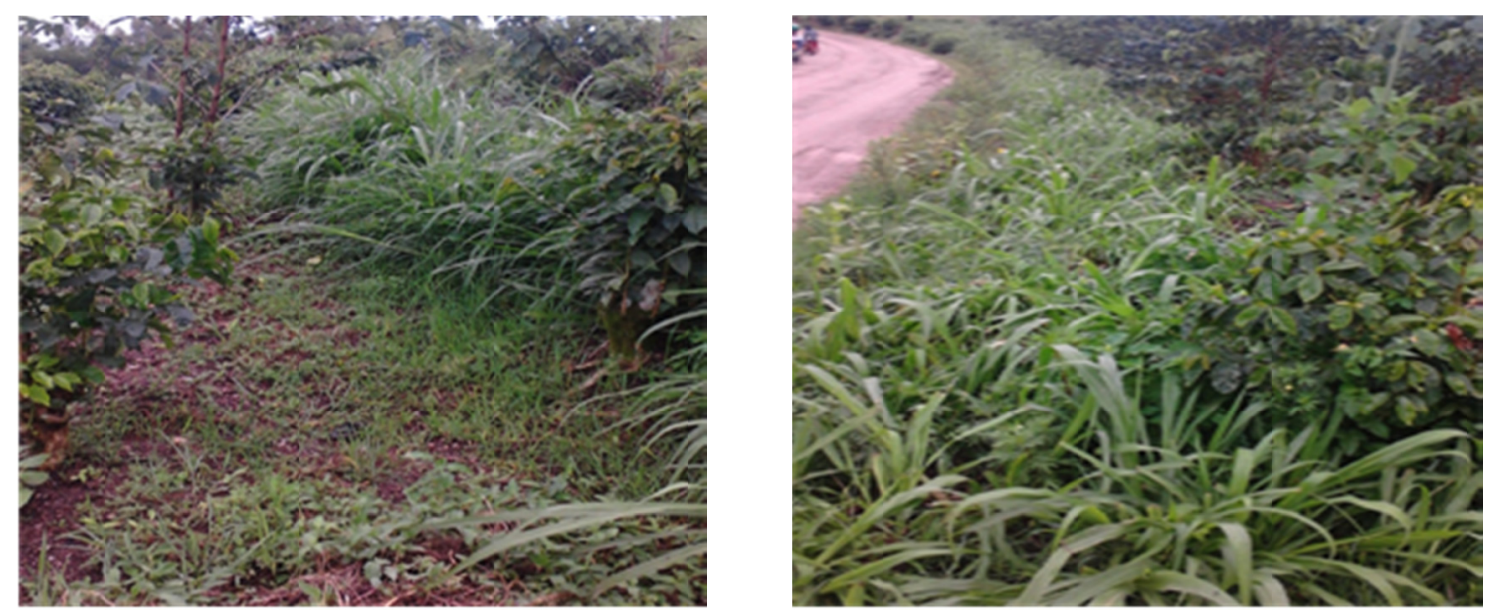

Figure 3. Pennisetum purpureum Schumach in coffee plantation. The photo was taken in Rwanda 2015

Intercropped coffee was facing a wide range of pests and diseases in Rwanda. Major pests known by small farmers who practiced intercropping in coffee trees are Hemeleia sp. (coffee yellow rust), anthracnose (Colletotrichum sp.), the bug Antestiopsis orbitalis (Hemiptera: Pentantomidae) and scales. Farmers have pointed out the problem of red ants that bite and disturb them when they were harvesting coffee beans, and sometimes they destroy the roots of young coffee plants and intercropped crops (e.g. Irish potatoes). The most prevalent insect (80\%) was Antestia spp. (Pentatomidae) while coffee rust was the most devastating disease known to coffee producers in Rwanda.

In most cases, the coffee production system still required the application of pesticides even if coffee was associated with food crops. The most common pesticides used in coffee plantation in Rwanda were Copper Oxychloride and Imidacloprid (Table 2). Chloropyriphos ethyl and Dimethoate were also used 3 years ago to control pests (termites, ants and sucking insects) in coffee trees.

Table 2. Pesticides used to control pathogens in coffee and percentage of farmers using them in their farms. Here, more than one answer was possible. It was in this context that the number of responses was greater that the population size (75 individuals)

\begin{tabular}{llll}
\hline Pesticides & Percentage & Targeted pest & Cost \\
\hline Imidacloprid & 78.7 & scales, antestia bugs & 7 USD/Kilogram \\
Copper Oxychloride & 9.3 & coffee rust & 300 USD/Kilogram \\
Chloropyriphos ethyl & 8 (banned) & ants and termites & 15 USD/Kilogram \\
Dimethoate & 28 (banned) & sucking insects & 6.50 USD/Liter \\
\hline
\end{tabular}

The survey data did not show any correlation between the use of chemical to control coffee pests and the practice of intercropping $(r=0.097)$. Data analysis showed a significant positive $(r=0.76, p<0.001)$ correlation between pesticide application and coffee production (Figure 4). This positive relationship was also influenced by different factors that can influence coffee yields such as the role of the intercropping system in coffee, soil fertility and environmental factors. 


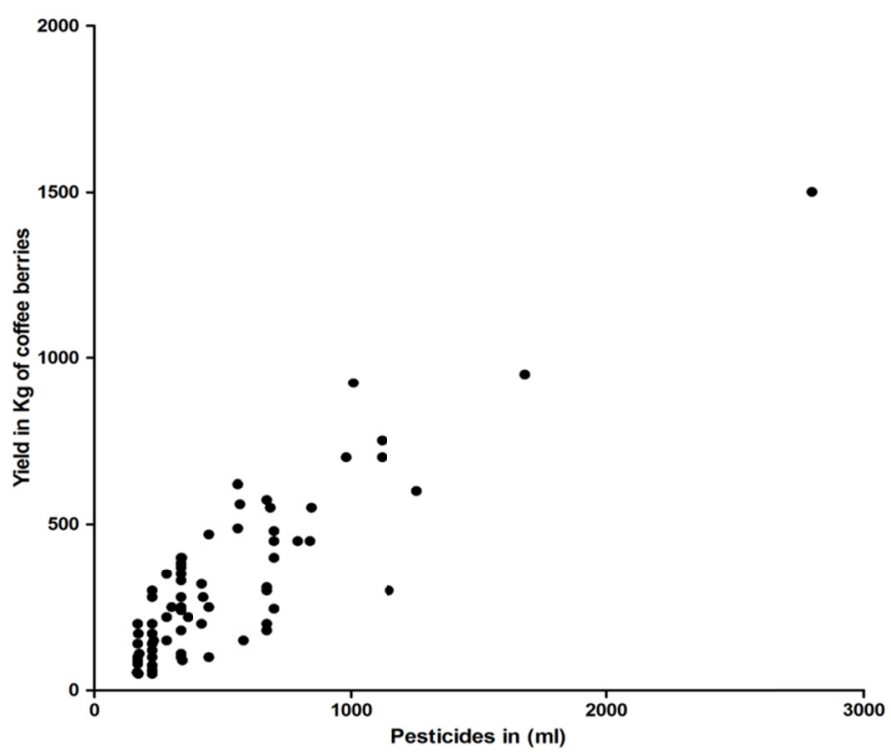

Figure 4. Correlation between pesticides ( $\mathrm{ml} / \mathrm{hectare})$ and yield $(\mathrm{kg} / \mathrm{hectare})(\mathrm{r}=0.7631)$. The graph was performed using Graph PadPrism 5

\section{Discussion}

If more than $33 \%$ of the farmers got their own seedlings from their plots because of a reduction in coffee tree productivity in both quality and quantity, the preparation of coffee seedlings is presently done by certified cooperatives in collaboration with the Ministry of Agriculture and Animal Resources and their use is promoted. Indeed, this reduction in yield was believed to be due to the existence of unmanaged and treated old coffee trees in rural areas, which leads to pest and disease dissemination among farms. In South America, particularly in Colombia, Mexico, Puerto Rico and Hawaii, endophyte pathogens of coffee (e.g. Colletotrichum coffeanum) (Incertae sedis: Gromerellaceae) were isolated from the seed tissue, and the old coffee plantations served as a reservoir (Vega et al., 2010). The main advantage of getting seedlings from the government or trained and certified cooperatives was that it made it possible to obtain healthy plants from the outset of cultivation and reduced the effect of plant pest populations. However, coffee growers who got seedlings from the Government of Rwanda were not allowed to intercrop coffee. The authorities encourage smallholders to practice the monoculture system in coffee production to obtain a better yield by reducing competition with other plants. However, the many advantages they could obtain from intercropping, such as the production of their own food, were not taken into account. In the future, the role of intercropping should be better taken into account for the range of benefit it brings, including its impact on pest management and the possibility of reducing the amount of money spent on buying pesticides and equipment. In practice, all the farmers interviewed used to intercrop coffee with at least one crop.

The period to grow coffee in Rwanda is often October-November or March, depending on seeds availability. Due to the lack of irrigation infrastructure, farmers try to match the planting period with the rain season. Even if the intercropping system generated income and subsistence for rural people; it was not practiced for the whole coffee growing period, except perennial crops, for example, banana or pineapples, citrus, and mangoes, which are associated with coffee for a long period of time. This practice offered the best potential in the first 3 years and after regeneration pruning. After that, when the coffee tree attains above $3 \mathrm{~m}$ high, intercropping with some plants (e.g., sweet potatoes and Irish potatoes) cannot be possible due to the high competition for light, space and probably water. During that period of maturity, other ways to practice intercropping should be investigated, taking into account the whole agro-ecosystems.

The most important food crops associated with coffee in Rwanda were beans, soybean beans, peas, colocasia, groundnuts, potatoes, cucumber, banana, cassava, peas, maize, sweet potatoes and pineapple. Beans but also soybean, even if less frequently intercropped with coffee, were both important to food supply but also because of their role in atmospheric nitrogen regulation, which might reduce the complements in mineral fertilizers that people apply. Soybean was found to have a significant positive effect on coffee productivity in Brasil (Paulo et al., 2001). However, soybean was less cultivated because it was presently not very well known; it was additionally difficult to harvest and took much time in the field. In the same way, according to Ratnadass et al. (2012), the 
association of coffee with peas had a double importance: it diversified income, increased nitrogen in the soil and played a major role in coffee pest management.

Beans (Phaseolus vulgaris L.) represented the most important crop associated with coffee in Rwanda. This point was already underlined by Allen et al. (1989). They constitute an important staple food for farmers and were grown in the whole country. Around 95\% of farmers produced beans in Rwanda (Blair et al., 2010). These results were similar to those of Carvalho et al. (2010) who showed that the beans associated with coffee significantly increased in production regardless of the fertilizer dose and crop management. In Rwanda, beans were an essential source of proteins for all farmers who are unable to get proteins from animal products. Second, the husk of beans controlled weeds in coffee plantations while their waste was used for mulching, cooking fuel, culinary activities and as compost for mushroom productions. The role of each crop associated with coffee must be evaluated, particularly their contribution to pest management, biodiversity conservation and coffee productivity.

The management of coffee plantations in combination with the increase of the area under cultivation is the major key to increasing production in Rwanda, and this is essential in a poor country with significant population growth. However, the increase of the area used for coffee production requires the destruction of natural vegetation in virgin areas as well as the modification of habitat and the natural environment in general. This modification may affect biodiversity and also the relative abundance of natural enemies and may, in extreme cases, cause their emigration or extinction (Pareto optimality). A transition to agro-ecological practices is thus needed to face the future challenge of Rwanda in a sustainable way and to maintain biodiversity as was observed in Central America (Bacon et al., 2008).

From our survey, it appeared that the main objective of intercropping of annual crops with Coffee in Rwanda was subsistence provision, agriculture diversification and increased coffee production in terms of quality and quantity. Apart from subsistence that farmers get from polyculture, they were diversifying agricultural commodities, controlling soil erosion, adding organic manure, keeping soil moisture in coffee, suppressing invasive plant species, constituting a refuge for beneficiary insects, creating alternative sources of natural enemies, and interfering with pest movement from one crop to another. However, none of the interviewed farmers that had used intercropping was fully aware of these benefits, and presently none of them has actively developed an approach to control pests with these techniques. On the contrary, in Latin America where intercropping has been used to control coffee pests (Avelino et al., 2011; Souza et al., 2010), the biological control of plant pests by changing habitat structure was still not applied or even known in the rural areas of Rwanda. The capacity building of decision makers on conservation agriculture is thus needed.

Different coffee pests and diseases are evocated by farmers even if they do not know their scientific names. The most pointed pests are Antestiopsis, coffee rust and scale insects Coccus spp. (Hemiptera: Coccidae). Massive agrochemicals used in pest control particularly for controlling pathogens are often thought to be the source of the potato taste in Rwandan coffee. However, there was no evidence that this could be the real cause.

As most farmers in Rwanda were working on hills or on slopes, soil erosion in and around coffee plots is usually managed, using a cover of Pennisetum purpureum. This plant is very prolific and was used for many purposes like feeding animals, mulching and supporting climbing beans. This species is known to act as pull-push, in controlling Lepidoptera such as maize stem borers (Khan et al., 2010). This means that maize associated with coffee where soil and wind erosion around coffee trees was controlled by P. purpureum was protected from stem borer while coffee was prevented from leaf miner damages. Species like Sesbania sesban L., an indigenous $\mathrm{N}_{2}$ fixing tree and Leucena leucocephala were also used at the edge of coffee plots (Nzeyimana et al., 2013) but at a low level due to the high cost (350USD $/ \mathrm{kg}$ of seeds) and effort required in seedling preparation. It was worthwhile to evaluate the role of intercropping in controlling soil erosion (runoff, splash effect, leaching) within coffee trees.

A large variety of agrochemicals was still used in the Republic of Rwanda. Around $98 \%$ of coffee farmers used pesticides to control coffee pests. The high number of coffee growers who used pesticides may be explained by the fact that the smallholders usually got pesticides and spraying equipment from the National Agriculture Export Board as credit and the cost was deducted from the price of coffee cherries when growers sold their produce to the washing station. This national institution promoted pesticide application for pest management because coffee production in Rwanda was an essential source of foreign currency, as most of the country's produce was sold in Western countries and standards were needed to access these highly demanding markets. To reach these standards, Rwanda had to prove the traceability in pesticide residue management, so it trained cooperatives in the safe use of pesticide for controlling pests in farmers' coffee plantations. Presently, the consequence of plant intercropping on pest control in coffee crop is not taken into consideration, and these 
practices should be investigated more in the future. Additionally, most insecticides are harmful to natural enemies or pollinators if they are not properly applied or when they are applied during a critical period, for instance, at the flowering stage. In Rwanda, pesticides are sometimes applied to the surrounding grass, and they automatically destroy the refuge of natural enemies and pollinating insects. An integrated approach must take place at different levels, from the coffee plantation to the farm surroundings, and should improve the availability of natural enemies and alternative sources of food for their optimal longevity and fitness. In that case, apparent competition may also play a role in reducing aphid in the coffee plot when non-economic aphid species are present in the surroundings and share the same parasitoids with pest species (Langer \& Hance, 2004). According to Landis et al. (2000), extra floral from Faba bean (Vicia fabae L.) were the primary source of food for adult parasitoids. This statement reveals that keeping flowering Faba bean in coffee or near coffee plantations helped to maintain alive parasitoid populations. It was thus advisable to provide natural enemies with alternative sources of food by intercropping coffee with Faba bean and other angiosperm plants.

Second, the use of pesticides to control pests in coffee plantations in Rwanda ignored the role and life cycle of predators, parasitoids and entomophtorales. Scales, aphids and Antestia spp. in coffee plantations might carry parasitoid egg, larva, pupa and insect pathogenic fungi. Then, the control of insects using insecticide meant eliminating both targeted insects and the parasitoid inside their host. Smallholders were not aware of the extinction of untargeted arthropods and their contribution to the regulation of the ecosystem.

\section{Conclusion}

This research revealed that intercropping was widely practiced in coffee plantations in Rwanda and that beans were the most frequent food crop intercropped with coffee. The main objective of intercropping in coffee in Rwanda was to diversify the agricultural production, land maximization, weed management and soil erosion control. However, farmers have never intended to apply intercropping as a way of pest control in coffee trees. Consequently insecticides were irrespectively still applied on the level of pest presence and even if intercropping was the main way to control coffee pests. Communities often seek studies that generate better information and increased participation in their development and conservation process and action that would be an ecological research helps to link both social and ecological research questions Given the advantages of intercropping and the environmental economic problems with current farming systems in terms of pest control, it seemed reasonable to continue research on the advantages of growing more than one crop simultaneously on the same piece of land to enhance biological control by managing the structure of the habitat. Furthermore, an introduction of an innovation in pest management in coffee in rural communities has to rely on the technology and cultural practices that exist in this area. It is also important to understand the farmers' perceptions and knowledge on pests and their natural enemies in order to enhance the participatory pest management approaches.

\section{Acknowledgements}

Anastase Harelimana benefits from a PhD grant from the Université catholique de Louvain. The authors are grateful to members of the ELIB teams for their technical assistance. Special thanks are due to all farmers for their hospitality during the survey. This paper is the 386BRC publication number of the Biodiversity Research Center, Université catholique de Louvain.

\section{References}

Albrecht, A., \& Kandji, S. T. (2003). Carbon sequestration in tropical agroforestry systems. Agriculture, Ecosystems \& Environment, 99(1), 15-27. https://doi.org/10.1016/S0167-8809(03)00138-5

Allen, D. J., Dessert, M., Trutmann, P., \& Voss, J. (1989). Common beans in Africa and their constraints. Bean production problems in the tropics (pp. 9-31). CIAT, Cali, Colombia.

Altieri, M. A., \& Koohafkan, P. (2008). Enduring farms: Climate change, smallholders and traditional farming communities (Vol. 6). Third World Network (TWN), Penang.

Avelino, J., Hoopen, G. M. T., \& DeClerck, F. (2011). Ecological mechanisms for pest and disease control in coffee and cacao agroecosystems of the neotropics. Ecosystem Services from Agriculture and Agroforestry Measurement and Payment (pp. 91-117). London: Earthscan.

Bacon, C. (2005). Confronting the Coffee Crisis: Can Fair Trade, Organic, and Specialty Coffees Reduce Small-Scale Farmer Vulnerability in Northern Nicaragua? World Development, 33(3), 497-511. https://doi.org/10.1016/j.worlddev.2004.10.002

Bacon, C. M. (2008). Confronting the coffee crisis: Fair trade, sustainable livelihoods and ecosystems in Mexico and Central America. MIT Press. https://doi.org/10.7551/mitpress/9780262026338.001.0001 
Bacon, C. M., Mendez, V. E., Gómez, M. E. F., Stuart, D., \& Flores, S. R. D. (2008). Are sustainable coffee certifications enough to secure farmer livelihoods? The millennium development goals and Nicaragua's Fair Trade cooperatives. Globalizations, 5(2), 259-274. https://doi.org/10.1080/14747730802057688

Bacon, C., Mendez, E., \& Brown, M. (2005). Participatory action research and support for community development and conservation: Examples from shade coffee landscapes in Nicaragua and El Salvador. Center for Agroecology \& Sustainable Food Systems.

Bainard, L. D., Klironomos, J. N., \& Gordon, A. M. (2011). Arbuscular mycorrhizal fungi in tree-based intercropping systems: A review of their abundance and diversity. Pedobiologia, 54(2), 57-61. https://doi.org/10.1016/j.pedobi.2010.11.001

Balota, E. L., \& Chaves, J. C. D. (2010). Enzymatic activity and mineralization of carbon and nitrogen in soil cultivated with coffee and green manures. Revista Brasileira de Ciencia do Solo, 34(5), 1573-1583. https://doi.org/10.1590/S0100-06832010000500010

Bigirimana, J., Njoroge, K., Gahakwa, D., \& Phiri, N. A. (2012). Incidence and severity of coffee leaf rust and other coffee pests and diseases in Rwanda. African Journal of Agricultural Research, 7(26), 3847-3852. https://doi.org/10.5897/AJAR11.955

Björkman, M., Hambäck, P. A., Hopkins, R. J., \& Rämert, B. (2010). Evaluating the enemies hypothesis in a clover-cabbage intercrop: Effects of generalist and specialist natural enemies on the turnip root fly (Delia floralis). Agricultural and Forest Entomology, 12(2), 123-132. https://doi.org/10.1111/j.1461-9563.2009. 00452.x/full

Blair, M. W., González, L. F., Kimani, P. M., \& Butare, L. (2010). Genetic diversity, inter-gene pool introgression and nutritional quality of common beans (Phaseolus vulgaris L.) from Central Africa. Theoretical and Applied Genetics, 121(2), 237-248. https://doi.org/10.1007/s00122-010-1305-x

Bleeker, P. M., Diergaarde, P. J., Ament, K., Schütz, S., Johne, B., Dijkink, J., \& Hiemstra, H. (2011). Tomato-produced 7-epizingiberene and R-curcumene act as repellents to whiteflies. Phytochemistry, 72(1), 68-73. https://doi.org/10.1016/j.phytochem.2010.10.014

Bucagu, C., Vanlauwe, B., \& Giller, K. E. (2013). Managing Tephrosia mulch and fertilizer to enhance coffee productivity on smallholder farms in the Eastern African Highlands. European Journal of Agronomy, 48, 19-29. https://doi.org/10.1016/j.eja.2013.02.005

Buechley, E. R., Şekercioğlu, Ç. H., Atickem, A., Gebremichael, G., Ndungu, J. K., Mahamued, B. A., ... Lens, L. (2015). Importance of Ethiopian shade coffee farms for forest bird conservation. Biological Conservation, 188(SP), 50-60. https://doi.org/10.1016/j.biocon.2015.01.011

Carvalho, A. J. de, Bastos de Andrade, M. J., Guimarães, R. J., \& Ramalho de Morais, A. (2010). Production systems of bean intercropped with establishing coffee crop or after stumping. Revista Ceres, 57(3), 383-392. https://doi.org/10.1590/S0034-737X2010000300015

De Beenhouwer, M., Aerts, R., \& Honnay, O. (2013). A global meta-analysis of the biodiversity and ecosystem service benefits of coffee and cacao agroforestry. Agriculture, Ecosystems \& Environment, 175, 1-7. https://doi.org/10.1016/j.agee.2013.05.003

Grez, A. A., \& Gonzalez, R. H. (1995). Resource concentration hypothesis: Effect of host plant patch size on density of herbivorous insects. Oecologia, 103(4), 471-474. https://doi.org/10.1007/BF00328685

Israel, G. D. (1992). Sampling the evidence of extension program impact. Citeseer.

Jassogne, L., Nibasumba, A., Wairegi, L., Baret, P. V., Deraeck, J., Mukasa, D., ... Van Asten, P. J. A. (2013). Coffee/Banana Intercropping as an Opportunity for Smallholder Coffee Farmers in Uganda, Rwanda and Burundi. Banana Systems in the Humid Highlands of Sub-Saharan Africa (Chap. 18, pp. 144-149). CABI. https://doi.org/10.1080/14735903.2012.714576

Khan, Z. R., Charles, A. O. M., Bruce, T. J. A., Hooper, A. M., \& Pickett, J. A. (2010). Exploiting phytochemicals for developing a 'push-pull' crop protection strategy for cereal farmers in Africa. Journal of Experimental Botany, 61(15), 4185-4196. https://doi.org/10.1093/jxb/erq229

Landis, D. A., Wratten, S. D., \& Gurr, G. M. (2000). Habitat management to conserve natural enemies of arthropod pests in agriculture. Annual Review of Entomology, 45(1), 175-201. https://doi.org/10.1146/ annurev.ento.45.1.175 
Langer, A., \& Hance, T. (2004). Enhancing parasitism of wheat aphids through apparent competition: A tool for biological control. Agriculture, Ecosystems \& Environment, 102(2), 205-212. https://doi.org/10.1016/j.agee. 2003.07.005

Machado, S. (2009). Does intercropping have a role in modern agriculture? Journal of Soil and Water Conservation, 64(2), 55A-57A. https://doi.org/10.2489/jswc.64.2.55A

Matusso, J. M. M., Mugwe, J. N., \& Mucheru-Muna, M. (2014). Potential role of cereal-legume intercropping systems in integrated soil fertility management in smallholder farming systems of sub-Saharan Africa. Research Journal of Agriculture and Environmental Management, 3(3), 162-174.

Mendez, V. E., Bacon, C. M., Olson, M., Morris, K. S., \& Shattuck, A. (2010). Agrobiodiversity and shade coffee smallholder livelihoods: A review and synthesis of ten years of research in Central America. The Professional Geographer, 62(3), 357-376. https://doi.org/10.1080/00330124.2010.483638

Mucheru-Muna, M., Pypers, P., Mugendi, D., Kung'u, J., Mugwe, J., Merckx, R., \& Vanlauwe, B. (2010). A staggered maize-legume intercrop arrangement robustly increases crop yields and economic returns in the highlands of Central Kenya. Field Crops Research, 115(2), 132-139. https://doi.org/10.1016/j.fcr. 2009.10.013

Mujawamariya, M. (2012). Identification of Potential Niches for Soybean cultivation in Farming systems of Eastern and Southern Rwanda (MSc Thesis, Wageningen, UR).

Nicholls, C. I., \& Altieri, M. A. (2013). Plant Biodiversity Enhances Bees and Other Insect Pollinators in Agroecosystems: A Review. Agronomy for Sustainable Development, 33(2), 257-274. https://doi.org/ 10.1007/s13593-012-0092-y

Njoroge, J. M., Waithaka, K., \& Chweya, J. A. (1993). Effects of Intercropping Young Plants of the Compact Arabica Coffee Hybrid Cultivar Ruiru 11 with Potatoes, Tomatoes, Beans and Maize on Coffee Yields and Economic Returns in Kenya. Experimental Agriculture, 29(3), 373-377. https://doi.org/10.1007/s13593012-0092-y

Nzeyimana, I., Hartemink, A. E., \& Graaff, J. (2013). Coffee farming and soil management in Rwanda. Outlook on Agriculture, 42(1), 47-52. https://doi.org/10.5367/oa.2013.0118

Paulo, E., Berton, R. S., Cavichioli, J. C., Bulisani, E. A., \& Kasai, F. S. (2001). Coffee productivity during intercropping with five leguminous species in the Western region of São Saulo state, Brazil. Bragantia, 60(3), 195-199. https://doi.org/10.1590/S0006-87052001000300006

Perfecto, I., \& Vandermeer, J. (1996). Microclimatic changes and the indirect loss of ant diversity in a tropical agroecosystem. Oecologia, 108(3), 577-582. https://doi.org/10.1007/BF00333736

Pumariño, L., Weldesemayat Sileshi, G., Gripenberg, S., Kaartinen, R., Barrios, E., Muchane, M. N., ... Jonsson, M. (2015). Effects of agroforestry on pest, disease and weed control: A meta-analysis. Basic and Applied Ecology, 16(7), 573-582. https://doi.org/10.1016/j.baae.2015.08.006

Ratnadass, A., Fernandes, P., Avelino, J., \& Habib, R. (2012). Plant Species Diversity for Sustainable Management of Crop Pests and Diseases in Agroecosystems: A Review. Agronomy for Sustainable Development, 32(1), 273-303. https://doi.org/10.1007/s13593-011-0022-4

Rushemuka, N. P., Bizoza, R. A., Mowo, J. G., \& Bock, L. (2014). Farmers' soil knowledge for effective participatory integrated watershed management in Rwanda: Toward soil-specific fertility management and farmers' judgmental fertilizer use. Agriculture, Ecosystems \& Environment, 183, 145-159. https://doi.org/ 10.1016/j.agee.2013.10.020

Russell, E. P. (1989). Enemies Hypothesis: A Review of the Effect of Vegetational Diversity on Predatory Insects and Parasitoids. Environmental Entomology, 18(4), 590-599. https://doi.org/10.1093/ee/18.4.590

Schroth, G., \& Ruf, F. (2014). Farmer strategies for tree crop diversification in the humid tropics: A review. Agronomy for Sustainable Development, 34(1), 139-154. https://doi.org/10.1007/s13593-013-0175-4

Siles, P., Harmand, J., \& Vaast, P. (2010). Effects of Inga densiflora on the microclimate of coffee (Coffea arabica L.) and overall biomass under optimal growing conditions in Costa Rica. Agroforestry Systems, 78(3), 269-286. https://doi.org/10.1007/s10457-009-9241-y

Soto-Pinto, L., Perfecto, I., \& Caballero-Nieto, J. (2002). Shade over Coffee: Its Effects on Berry Borer, Leaf Rust and Spontaneous Herbs in Chiapas, Mexico. Agroforestry Systems, 55(1), 37-45. https://doi.org/ 10.1023/A:1020266709570 
Souza, H. N., Cardoso, I. M., Fernandes, J. M., Garcia, F. C. P., Bonfim, V. R., Santos, A. C., ... Mendonça, E. S. (2010). Selection of Native Trees for Intercropping with Coffee in the Atlantic Rainforest Biome. Agroforestry Systems, 80(1), 1-16. https://doi.org/10.1007/s10457-010-9340-9

Souza, H. N., Graaff, J., \& Pulleman, M. M. (2012). Strategies and Economics of Farming Systems with Coffee in the Atlantic Rainforest Biome. Agroforestry Systems, 84(2), 227-242. https://doi.org/10.1007/ s10457-011-9452-X

Straub, C. S., Simasek, N. P., Dohm, R., Gapinski, M. R., Aikens, E. O., \& Nagy, C. (2014). Plant diversity increases herbivore movement and vulnerability to predation. Basic and Applied Ecology, 15(1), 50-58. https://doi.org/10.1016/j.baae.2013.12.004

Vega, F. E., Simpkins, A., Aime, M. C., Posada, F., Peterson, S. W., Rehner, S. A., ... Arnold, A. E. (2010). Fungal endophyte diversity in coffee plants from Colombia, Hawai'i, Mexico and Puerto Rico. Fungal Ecology, 3(3), 122-138. https://doi.org/10.1016/j.funeco.2009.07.002

Wang, Z., Bao, X., Li, X., Jin, X., Zhao, J., Sun, J., ... Li, L. (2015). Intercropping Maintains Soil Fertility in Terms of Chemical Properties and Enzyme Activities on a Timescale of One Decade. Plant and Soil, 391(12), 265-282. https://doi.org/10.1007/s11104-015-2428-2

Wezel, A., Casagrande, M., Celette, F., Vian, J.-F., Ferrer, A., \& Peigné, J. (2014). Agroecological Practices for Sustainable Agriculture: A Review. Agronomy for Sustainable Development, 34(1), 120. https://doi.org/ $10.1007 / \mathrm{s} 13593-013-0180-7$

\section{Copyrights}

Copyright for this article is retained by the author (s), with first publication rights granted to the journal.

This is an open-access article distributed under the terms and conditions of the Creative Commons Attribution license (http://creativecommons.org/licenses/by/4.0/). 